\title{
SECONDARY STUDENTS PERFORMANCE IN ENGLISH VIRTUAL ENVIRONMENT AT ACULMAITL SCHOOL MEXICO.
}

\author{
1Marisol Márquez Martínez. ²Arjulayana \\ B.A Pedagogy and English teacher at Universidad Lucerna-Mexico. \\ Teacher Training and Education of the University of Muhammadiyah Tangerang-Indonesia. \\ Email: marisol.marquez@lucerna.edu.mx \\ Email: Arjulayana@umt.ac.id
}

\begin{abstract}
The purpose of this research was to relate the extent to which the virtual learning environment improved the English language performance of first-year secondary school students in Mexico. This research had a quantitative approach with a correlational and explanatory scope to see how the variables were related, observing how reliable a virtual environment could be. In short, the importance of the study is that students develop digital skills and knowledge, so that they could take advantage of the content and make use of the digital teaching materials and resources presented on the platform. The study was carried out using non-probabilistic sampling since the subjects are 11 adolescents from the 1st year of secondary school, and they were chosen for using the platform during the school year. Taking into consideration different factors such as the individual and the context live in. On the individual development, to cognitive variables such as learning style, prior learning, intelligence, and learning, while the latter involves motivational variables. In the context, there are three variables: the first is institutional re-use, the school center, the school management, teacher training, and the school environment.
\end{abstract}

Keywords: Virtual learning environment, English performance, secondary students, English language. 


\section{INTRODUCTION}

Nowadays, how to implement classes through the platform has been challenging, since in Mexico, the classes are online due to the pandemic we are across around the world. The study is to discern visually how an educational platform supports current teaching, the essentiality of knowing how to use it and how to rescue its benefits. The study is to optically discern how the educational platform is a support in the current teaching, the essentiality of knowing how to use it, and its benefits that will make the students learn and understand the good use of technology. It is essential to resume the collaborative, autonomous, and motivating work of the students. The objective of learning a language is to communicate using the four skills of the language, productive (written and oral), receptive (reading and listening).

This leads us to the research question which is: What is the performance of the English language in virtual environments?, having as a hypothesis: The performance of the English language through virtual environments provides the necessary tools for good language acquisition. It describes that a distinction, a "virtual learning environment" (VLE) or "learning management system" designed to act as a focus for students' learning activities and their management and facilitation, together with the provision of content and resources necessary to help make the activities successful. (Stiles, 2000). Another important point is assessment online the test used showed validity, it is believed that without assessment, it is impossible to know what students have learned about the content and how to demonstrate their knowledge, skills, attitudes, and values through various 
Globish (An English-Indonesian journal for English, Education and Culture

Vol. 10, No.2, July 2021,

P-ISSN: 2301-9913, E-ISSN: 2597-9132

DOI: http://dx.doi.org/10.31000/globish.v7i2

tasks. In addition, the ignores the quality of such learning. (Secretaría de Educación Pública, 2018).

\section{THEORETICAL REVIEW}

\subsection{ACADEMIC PERFORMANCE}

This can be measured with pedagogical evaluations, understood as the set of procedures that are planned and applied within the educational process to obtain the necessary information to assess the achievement, by the students, of the purposes established for this process.

Academic performance is how the achievements of both the teacher and the student are visualized, it is retaking with indicators, concerning (Caballero, Abello, \& Palacio, 2007). It can be mentioned that academic performance implies the fulfillment of the goals, achievements, and objectives established in the program or subject that a student is studying expressed through grades, which are the result of an evaluation that implies the passing or not of certain tests, subjects or courses. As mentioned before, this research is based on looking at English language performance, not only on a quantitative assessment but also on what the student can produce on his/her own using the knowledge acquired and learned during the school year. Barchard (2003) found that cognitive ability and personality aspects were statistically predictive of academic performance. It is therefore essential that students have both intrinsic and extrinsic motivations. It is, therefore, necessary for the student to have digital skills so that he/she can take advantage of the contents and make use of the digital teaching materials and 
Globish (An English-Indonesian journal for English, Education and Culture

Vol. 10, No.2, July 2021,

P-ISSN: 2301-9913, E-ISSN: 2597-9132

DOI: http://dx.doi.org/10.31000/globish.v7i2

resources presented on the platform. It is well said that today's society, the "knowledge society"

says that, "Science and technology are conquering many areas of life. It is about changing the

way we think, feel and act with axioms of perception, a fundamental aspect of motivation" (Cardona, 2002). Hence the need to look at how reliable a virtual environment is for language acquisition, whether it provides sufficient learning tools for the learner, and what role the teacher plays.

\subsection{VIRTUAL LEARNING ENVIRONMENTS}

There is a methodological approach to educational models and that is Virtual Learning Environments (VLE), moving from a classroom to a virtual classroom, meaning that it is mediated by technology. In the words, it describes a distinction, a "virtual learning environment" (VLE) or "learning management system" designed to act as a focus for student learning activities and their management and facilitation, together with the provision of content and resources necessary to help make the activities successful. (Stiles, 2000),

This includes the platform used for this study, which is a Learning System Management System (LMS), which has a wide variety of tools of which we highlight instant messaging, forums, whiteboards, interactive book and is also allowed to develop.

Therefore, innovative educational models should facilitate an interactive, synchronous, and asynchronous learning environment in which teachers participate in students' learning and act as mentors and operators. Learners will be subject to change through creative technology and by working with creative technology, instructional materials, information resources, and digital content. The incorporation of information technology in education has improved the quality of 
Globish (An English-Indonesian journal for English, Education and Culture

Vol. 10, No.2, July 2021,

P-ISSN: 2301-9913, E-ISSN: 2597-9132

DOI: http://dx.doi.org/10.31000/globish.v7i2

teaching and enabled better management of the data that learners discover and interpret.

(Aguilar, 2012).

\section{METHOD}

The method used in this correlational research is a non-experimental cross-sectional design because the variables to be measured: performance in the English language in virtual environments will not be manipulated, only observed on students in the first year of secondary Aculmaitl school in Acolman, Mexico State, which was measured on a single occasion. It was carried out employing non-probabilistic sampling since there are 11 teen students, and they were chosen for using the platform acquired during the school year. The study was evaluated by the oral part of the students' presentations in which they talked about personal information, describing what they did on their past holidays, and, finally, their plans and general experience. Evaluated through a rubric. In addition, students answer a level test applied by a website, according to that test they must get between A1A2 based on the Common European of References of languages. Besides, the test focuses on grammar, vocabulary, reading, listening, and writing. Moreover, the basis for obtaining this assessment is described as two types of evidence, a single criterion used to compare the 
Globish (An English-Indonesian journal for English, Education and Culture

Vol. 10, No.2, July 2021,

P-ISSN: 2301-9913, E-ISSN: 2597-9132

DOI: http://dx.doi.org/10.31000/globish.v7i2

assessment results expressed as a condition with the results of other students when the criteria are compared, at a defined level of performance. (Hernandez).

\section{FINDING AND DISCUSSION}

When an information-gathering tool is applied, the process corresponding to that analysis is carried out. This is because the information provided is about the tests conducted in this research, two times, the first was an online level test provided by a platform, evaluating grammar, vocabulary, reading, writing, listening skills. It is mentioned that doing a test is the moment of reflection and, at the same time, of demonstration (Anijovich, 2021). Teachers need to know if a student can apply the knowledge not only memorize it, students must be conscious in the process they are in. The results were not good, the highest scored was 8.4 , and the lowest 4.5 having an average of 6.9 from the class.

An assessment does not always assume that the learner has acquired or learned the language skills because many factors are involved. Such as technological skills, reading comprehension, reading comprehension, motivation, above all the context they live in, the students carried it out at home, taking into account that the conditions are not favorable for everyone, referring to the interference they can have. For example, it is not possible to 
Globish (An English-Indonesian journal for English, Education and Culture

Vol. 10, No.2, July 2021,

P-ISSN: 2301-9913, E-ISSN: 2597-9132

DOI: http://dx.doi.org/10.31000/globish.v7i2

have a suitable place to study, family is there, sometimes the instructions are clear, students

do not have good reading or listening comprehension, or signal problems, and those things make the student feel stressed and anxious, affecting their performance. While in the classroom, it is possible to observe the student performing adequately. On the other hand, the oral part the student presented in class, through an exhibition last 5 minutes per student, which showed mastery of the topic through a global explanation of the requirements, was as natural as possible. (Mugford, 1999) comments that "it does not matter how well a person knows a language's grammar if he or she does not know how it must be used for successful communication, or how people use it in their native environment."

Students have some trouble in pronunciation, vocabulary being that the oral part indicates the integration of other skills, and students must do it through practice by the time they exchange information in their native language. As a teacher. As a teacher, we know that speaking part is the creation of the knowledge acquired. The speaking part was evaluated with a rubric that focused on pronunciation, fluency, content, accuracy. It can be mentioned that it fulfilled the expectations. Most of the students were able to express what was required, but this was possible because every 15 days the students make oral presentations on different topics according to the school content. Speaking is not just exchanging information, it is a high-complete mental cognitive process that enhances comprehension, interaction, memory, reflects on the process and the experience with the target language. (Torky, 2006).

The results were good, but it is not a platform for students to acquire language skills, as language learning is developed through practice and many factors play a role in this. As we 
Globish (An English-Indonesian journal for English, Education and Culture

Vol. 10, No.2, July 2021,

P-ISSN: 2301-9913, E-ISSN: 2597-9132

DOI: http://dx.doi.org/10.31000/globish.v7i2

can see in the chart, it refers to the test results, students answer a digital level test.

Notwithstanding, the relation between the level online test and the oral part is gathered since both are an outcome of a learning process.
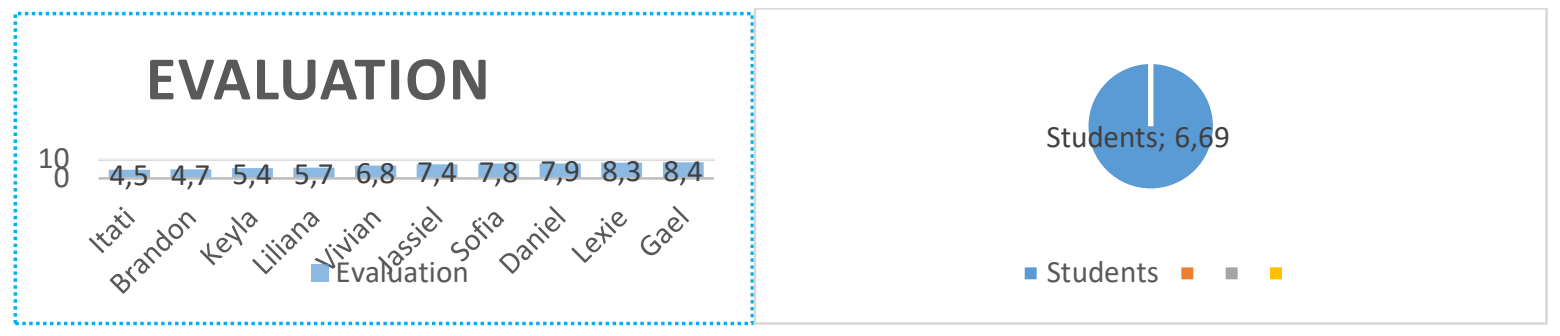

Evaluation test

Average

\section{CONCLUSION}

The findings found with this research according to the correlation analysis among English language performance and virtual learning environment it existed a relation not as it was expected since students evaluation scored was low, meanwhile in their speeches can communicate using basic information according to their English level acquired and learned during this school year, studying online faces many disadvantages, students answer the task but are something that is not trustworthy because a student can cheat in a test by just searching online any word he or she needs, also somebody can be there helping them. Another problem facing during this research was that the sample was too small, only 11 students, it was not a standardized test applied by an external institution, it was just chosen by a platform according to the content seen in the curriculum.

In today's knowledge-based society, the use of integrated IT in education is advancing rapidly, opening space for a variety of face-to-face, personalized, mobile, and cloud-based 
Globish (An English-Indonesian journal for English, Education and Culture

Vol. 10, No.2, July 2021,

P-ISSN: 2301-9913, E-ISSN: 2597-9132

DOI: http://dx.doi.org/10.31000/globish.v7i2

educational modalities with IT and virtual support. It means that the teacher plays an

important role since he or she oversees the activities and at the same time has an acquaintance with the student. Meanwhile, the students must be autonomous, active, selftaught, disciplined, responsible. The importance is to identify which role is going to play. On the whole, the platforms used for virtual education offer a variety of features, but not always enough, so it is important to find a communication strategy that can track learning activities and developments promptly that they can track learning activities and developments promptly.

So a suggestion would be how important and how do the teacher and the virtual environment influence English language performance or acquisition?.

\section{REFERENCES}

Aguilar, M. (2012). Aprendizaje y Tecnologías de Información y Comunicación: Hacia nuevos escenarios educativos. . Revista latinoamericana de Ciencias Sociales, Niñezy Juventud, 10 (2),, 806. Obtenido de Aprendizaje y Tenologías de Informacióny Comunicación: Hacia nuevos escenarios. Educativos. : https://www.redalyc.org/pdf/773/77323978002.pdf

Anijovich, R. (29 de abril de 2021). Infobae. Obtenido de Rebeca Anijovich y un encuentro para pensar la evaluación en pandemia: https://www.infobae.com/educacion/2021/04/29/rebeca-anijovich-y-un-encuentro-parapensar-la-evaluacion-en-pandemia/

Aula School Mangement. (2021). Plataformas educativas ¿Qué son y para qué sirven? Obtenido de https://www.aula1.com/plataformas-educativas/

Barchard, K.A. (2003). Does Emotional Intelligence Assist in the Prediction of Academic Success? 
Globish (An English-Indonesian journal for English, Education and Culture

Vol. 10, No.2, July 2021,

P-ISSN: 2301-9913, E-ISSN: 2597-9132

DOI: http://dx.doi.org/10.31000/globish.v7i2

Educational and Psychological Measurement, 63(5), 840-858. DOI: $10.1177 / 0013164403251333$

Caballero D, C. C., Abello LI, R., \& Palacio S, J. (2007). Redalyc. Obtenido de https://www.researchgate.net/publication/28233342 Relacion del burnout y el rendi miento academico con la satisfaccion frente a los estudios en estudiantes universit $\underline{\operatorname{arios}}$

Cardona, G. (Mayo de 2002). Edutec. Obtenido de https://www.edutec.es/revista/index.php/edutec-e/article/view/542

Mugford, G. (1999). Sociolinguistic Competence in Foreign Language Teaching: The Secrets behind Language Grammar. Obtenido de https://rafangel.wordpress.com/2005/04/23/meetthose-who-have-personified-my-moments/

Parra, A. E. (18 de diciembre de 2009). AMBIENTES VIRTUALES DE APRENDIZAJE. Obtenido de http://investigacion.ilce.edu.mx/panel control/doc/Rayon Parra.pdf

Secretaría de Educación Pública. (2018). Evaluar para aprender. La evaluación formativa y su vinculo con la enseñanza y aprendizaje. Obtenido de https://www.planyprogramasdestudio.sep.gob.mx/evaluacion/pdf/cuadernillos/Evaluarpara-aprender-digital.pdf

Stiles, M. (Abril de 2000). Effective Learning and Virtual Learning Environment. En: EUNIS 2000, Towars Virtual Universities, Instytut Informatyki Politechniki Poznan. Obtenido de http://citeseerx.ist.psu.edu/viewdoc/download;jsessionid=11F16AF4F614F32C2C5E91632 747BDE6?doi=10.1.1.616.2633\&rep=rep1\&type=pdf

Torky, S. A. (s.f.). What is speaking :- ERIC. Obtenido de The Effectiveness of a Task- Based Instruction program in Developing the English Language Speaking Skills of Secondary Stage Students: https://files.eric.ed.gov/fulltext/ED523922.pdf 
Globish (An English-Indonesian journal for English, Education and Culture Vol. 10, No.2, July 2021,

P-ISSN: 2301-9913, E-ISSN: 2597-9132

DOI: http://dx.doi.org/10.31000/globish.v7i2 